\title{
THE JARGONS USED BY BALINESE DANCER OF FEMALE AT SANGGAR SENI MANIK UTTARA
}

\author{
Stuti, N.N.W. \\ English Education Department, Ganesha University of Education \\ e-mail: nyoman.wiswa.stuti@gmail.com \\ Ramendra, D. P. \\ English Education Department, Ganesha University of Education \\ e-mail: putu.ramendra@undiksha.ac.id
}

Utami, I.A.M.I

English Education Department, Ganesha University of Education e-mail: istriutami@undikdha.ac.id

\begin{abstract}
This study aimed to know the form of jargons used by Balinese Dancer of female at Sanggar Seni Manik Uttara, to know the meaning of each jargons used by Balinese Dancer of female at Sanggar Seni Manik Uttara, and to know the function of Jargons used by Balinese Dancer of female at Sanggar Seni Manik Uttara. This study was designed by descriptive qualitative in which Sanggar Seni Manik Uttara chosen as the setting of the study. The main instrument of this study was the researcher itself which supported by the recorder, camera, interview guide and observation to collect the data. This study was supported by two subjects, the Instructor and student of Balinese Dancer who gave the researcher explanation about the meaning of the form of jargons used by Balinese Dancer of Female at Sanggar Seni Manik Uttara. From the explanation of the Instructor and student of Balinese Dancer, there are found 41 jargons which consists of 17 compounding, 2 reduplications, and10 Affixations of word formation process, then there are 10 nouns and 2 verbs of word classes. Those jargons were used to make the communication among the Balinese Dancer easier. Moreover, it can build the solidarity of each team when talk about the Balinese Dance.
\end{abstract}

Keywords: Jargons, Balinese Dance, Word Formation Process

\section{INTRODUCTION}

Communication is important in which the people use language. It is the activity which used to convey the information (Agarwal \& Garg, 2012). To develop the communication people should be mastered the language first. Language is a tool to maintain social's relation through sharing ideas, thought, opinions and feeling to other people in order to make their communication, so people can convey their information well (Armstrong \& Ferguson, 2010). Besides that, language also deals with a culture in which it is a characteristics of group of people in which characterize everything from language, social habit, and art (Solgi \& Tafazoli, 2018). They also said that culture 
makes everything is unique of each country, because it is constitute the belief and values of the people in society. There is a place that popular with their culture. Bali is one of popular place includes the interesting culture. Traditional Dance is very interesting to be introduced to the foreign or the people who not stay in Bali. Traditional dance in Bali is commonly called Balinese Dance. Balinese Dance is challenging, because its movements involved all of part of body from head, eye, neck, hand, feet, and expressions. It is popular in society indeed Balinese Dance has been recognized by UNESCO (United Nations Educational, Scientific and Cultural Organization) that used to promote the Indonesia Tourism internationally. Exactly, there are male and female in Balinese Dancer. Specifically, male and female Balinese dancer is different and it can be seen from the term and movement that exists in Balinese Dance itself. Yet, this study focused on female dancer only, because mostly the Balinese dancer in Bali is female. Besides, female has more attractive appearance in dance. Female can make the dance become more interesting with their beauty. In this case, the dancers of Balinese Dance will use the jargons when they give an instruction or talk about Balinese dance. It is done in order to make the dancer easier to communicate to the people who involved in Balinese Dance. Besides, jargons used will help the dancer and the people around to manage the time in conduct the communication and they should make the time efficiently. Then, in conducting the practice dance, the dancer or people should know the term and vocabulary that involved in communication about Balinese Dance generally. The most important things that should people know are the jargons that used in Balinese Dance when the instructor does a communication with his students. Jargon belongs to language variety which means the word that has specialized vocabulary which used in a particular profession or job with unfamiliar term (Wright, 2010). In this study, the researcher explained the form, meaning, and function of jargons used by dancer on female which got the information from Sanggar Seni Manik Uttara..

\section{METHOD}

This study was conducted with qualitative approach which concuted at Sanggar Seni Manik Uttara. The researcher helped by two interviewee in gaining the information, those were Instrucator and Student of Balinese Dancer. Then, the main instrument of this study was the researcher itself which helped by interview guide and observation to collect the data.

\section{FINDING AND DISCUSSION}

Culture has a good relation, because culture is unique. Solgi \& Tafazoli (2018) mentioned that culture is the characteristics of group of people which characterize the social habit, language, and the art of culture itself. Talk about culture and art. There is an art tha $t$ can found in a popular place that is Bali with its own Balinese Dance that popular in the tourism world. The researcher chooses the Balinese Dance, because Balinese dance already recognized by the UNESCO United Nations Educational, Scientific and Cultural Organization). Maharani in Fardah (2015) mentioned Balinese Dance recognized by UNESCO is used to promote the Indonesia Tourism internationally. Then, to make people easier to understand about the Balinese Dance, they should know the jargon of the Balinese Dance itself especially on Female. the researcher found 41 jargon used by female Balinese Dancer at Sanggar Seni Manik Uttara that classified on word formation process and word class. There are 17 
compounding, 2 reduplications, 10 affixations, and 12 word classes that consist of 10 nouns and 2 verbs.

\section{a. Compounding}

Compounding is a word formation process which consist in the two or more combinations word that free or independent word that produce a new word and the meaning itself (Nurhayati, 2016). Then, from the explanation about the compounding word formation process, it related to the result of this study that the word of jargons which categorized to compounding are 17 jargons.

1. Ulu Wangsul

Ulu Wangsul belongs to compounding of word formation, because there are two word that can stand alone or has their own meaning, but those word can be combined become a new word. Ulu means eight in Balinese and Wangsul means the dynamic movement that move smoothly and string. Therefore, Ulu Wangsul means the movement of neck in Balinese Dance that move shaped the number of eight to the right and to the left string and smoothly.

2. Ngotag Leher

Ngotah Leher also belongs to compounding, because there are two different words that free to combine as a new word. Ngotag means the movement to the right and to the left strongly. Then, Leher means neck in Balinese. So, if those were combined it means the movement of the neck which moves to the right and to the left slow and strongly.

3. Agem Kanan

Agem Kanan is the word formation that belongs to the compounding. It divided into two words that have different meaning, but it can be combined to one another. Agem means the basic position of Balinese Dance which involved head, hands that one of them equal to the eyes and breast, body skewed to the left or the right, legs is bended, and the bottom follows where the body skewed. Kanan means Right in Balinese. Then, Agem Kanan in context of Balinese Dance means position of body that skewed to the right side. Then, the right hand position is on equal to the eyes on the right side, while the left hand position is on the left side and equal to the breast. Then, the palms of two hand is facing forward, the mother finger of both of hand be folded to the palm so there are only four fingers that facing up as the hand position of Agem. Furthermore, the feet position as follows the left foot is stand in front of the right side that direct to the left corner and the right foot is stand behind the left foot which direct to the right corner, then the knee is banded and opened larger pointing to each corner and also all of the toe is facing up or as known as nyelekenting in Balinese Dance. Moreover, the bottom/gluteus is facing to the left side.

\section{Agem Kiri}

Agem Kiri belongs to the compounding of word formation, because there are two words that can be combined becomes new word and meaning. Agem means the basic position of Balinese Dance movement. It involved the head which fall down to the right or to the left, feet that bended and one of them ahead, body skewed to the right or left side, hands equal to the eyes and the breast, and bottom is following where the body fall down. Then, Kiri means left in Balinese, it means everything conducted to the left. Therefore, it can be defined that Agem Kiri means the position of body that skewed to the left side. Then, the left hand position is on equal to the eyes on the left side, while the right hand position is on the right side and equal to the breast. Then, the palms of two hand is facing forward, the mother finger of both of hand be folded to the palm so 
there are only four fingers that facing up as the hand position of Agem. Furthermore, the feet position is as follows the right foot is stand in front of the left side that direct to the right corner and the left foot is stand behind the right foot which direct to the left corner, then the knee is banded and opened larger pointing to each corner. Then, all of the toes is facing up or as known as nyelekenting in Balinese Dance. Moreover, the bottom/gluteus is facing to the right side.

5. Ngocok Rangki

Ngocok Rangki can be classified to the compounding of word formation. There are two words are Ngocok and Rangki that can stand alone and has different meaning, but they can be combined becomes a new word and different meaning. Actually, Ngocok means shaking or convulse. Then, Rangki means a curtain that usually installed on the entrance of the stage. So, if the researcher combines the word Ngocok Rangki mean convulsing the curtain of the entrance of the stage. Yet, in Balinese Dance it means the hands movement which the two hands straight forward, the palms facing forward, and the fingers are facing up. Then, the characteristics of this movement is those two hands that straight forward is shaken contrary. The meant by contrary is the right hand is move to the right side and the left hand is move to the left side and revert concurrently. This movement can be seen in Condong Balinese Dance. Furthermore, this movement is seen like convulse the curtain on the entrance of the stage.

6. Nadab Gelung

Nadab Gelung belongs to the compounding, because there are two words provided which can be combined become a new word and meaning. Nabdab means the movement of hand that used to touch everything. Meanwhile, Gelung means an accessory of Balinese Dancer that used on a head, Gelung same as crown royalty. So, the Nabdab Gelung movement can be defined as the movement that touching an accessory that used on the head. Generally, the movement of nabdab gelung is the two hands involve. The right hand is touching the head in which only the forefinger that touch the head or the accessory. Then, the left hand is taking a position equal to the breast, such as the Agem.

7. Mungkah Lawang

Mungkal Lawang belongs to compounding, because there are two words that combined which produce a new word. Mungkah means open and Lawang means gateway that provide at Balinese house. So, from the description, the researcher can define Mungkah Lawang is opened the door. Yet, in Balinese dance, Mungkah Lawang is interpreted as the dancer opened the gate of the stage indvidualy in Dance. The movement which is the two hands is equal in front of the face. The palms are facing forward and the fingers are facing up. Moreover, the position of feet, body, and the bottom same as Agem Kanan in which the left foot is in front of right foot, the body fall down to the right side, and the bottom skew to the left side.

8. Luk Nerutdut

Luk Nerutdut consists of two words in which has different meaning, but those can be combined becomes new word. Luk means indentation of the hands and body. Meanwhile, nerutdut means the movement tandem. So, Luk Nerutdut means the movement of hands that tandem. In Balinese Dance, Luk Nerutdut means the movement of hands which move tandem up and down. Moreover, this movement is move after the Balinese Dances do the Agem Kanan or Agem Kiri. When the hands go up along, the palms are facing up. Then, when the hands god down along, the palms are facing down. 
Then, at the time of hands go down along the body is going down too and look like squat down.

\section{Ngombak Ngangkel}

Ngombak Ngangkel belongs to compounding of word formation. There are two words ngombak and ngangkel. Ngombak means wave in English, while ngangkel means move up to the right side and to the left side. Thus, ngombak ngangkel in Balinese Dance means the movement of hands and the body along to the right side and to the left side seem to the dancer push their body to the right and left side. Furthermore, when the dancers push their body to the right and left side, the dancer's wrists will rotate automatically. When the body pushed to the right the wrists move to the right side, so the palms facing to the right side and the fingers rotate to the left side and take a semicircle position and vice versa. Through the movement, ngombak ngangkel is characterizing as the wave which up and down.

\section{Tapak Sirang Pada}

Tapak Sirang Pada is the movement of Balinese Dance that belongs to compounding of English word formation. There are three words that have different meaning, but those can produce a new word and new meaning when they are combined. Tapak means foot that used to step the ground, sirang means the position of each feet were equal, and pada means the position already fitted. Yet, Tapak Sirang Pada in Balinese Dance means the position of foot. The foot is stand up followed by the knee that banded and opened direct to each corner. Then, the heels of the feet are meets, so the toe open and find the corner automatically which already equal and fitted.

11. Lelasan Megat Yeh

Lelasan Megat Yeh also belongs to the compounding of word formation. There are three words that combined and it becomes a parable in Balinese Dance jargon. Actually, lelasan in English it means lizard, megat means crossing, and Yeh means waterway. So, if it combined it means the lizard is crossing the waterways. Yet, in Balinese Dance it not means the dancer crossing the water, but the movement of the lizard be imitated by the dancer. The dancer is taking position to the left or right corner with the heel on tiptoe is shifting quickly and followed by the hands which the right or left hand is in front of the breast, and the other hand extend to the right or left side in which the fingers is facing back.

12. Gelatik Nuwut papah

Gelatik Nuwut Papah also belongs to the compounding of English word formation. Each word of Gelatik Nuwut Papah can be described and they can have a new meaning when they were combined. Gelatik in Balinese means a kind of bird that can be seen in Bali, Nuwut means following or through even crossing in Balinese and Papah means the steam leaves of coconut tree. The Gelatik Nuwut Papah is the movement that likens the Balinese Dance as bird walk on the steam leaves of coconut tree. As we know, the steam leaves of coconut tree is not too large and for making the walk balanced, so the bird walked through crossing his legs to the right or left side. So, in Balinese Dane it can be mentioned as the walking movement in which the dancers move through crossing their legs to the right or left side.

13. Piles Kanan

Piles kanan belongs to compounding of English word formation. There are two words that combined i.e. Piles and Kanan. Piles means rotating the heel to the right or left side with the position on tiptoe and the knee is banded, then kanan means right. Therefore, Piles Kanan means the heel is rotating to the middle between right and left 
foot. The heel is on tiptoe and the knee is banded. This movement is used to change Agem Kiri to Agem Kanan. The right hand is equal to the right eye which the palms facing to the left side and the fingers facing forward. While, the left hand aligned with the breast which the palms still facing forward. Then, the body and head are falling down to the right.

\section{Piles Kiri}

Piles Kiri is the same as Piles Kanan. It belongs to compounding too that consists of two words i.e. Piles and Kiri. Piles mean rotating the heel inside to the right side or left side. Kiri means left in English. So, in this case Piles Kiri means rotating the left heel inside to the right side which the heel on tiptoe and the knee is banded. This Piles Kiri is used to change the position of Agem Kanan to Agem Kiri. Therefore, the hands position of Piles Kiri is the left hands equal to the left eye which the finger is facing forward and the palm facing to the right side. Then, the right hand equals to the breast and the palm facing forward. After that, the body and the head is falling down to the left side.

\section{Kidang Rebut Muring}

Kidang Rebut Muring in English word formation belongs to compounding. There are three words Kidang, Rebut, and Muring that combined. Kidang means deer in English, Rebut is disturbed, and Muring means bug looks like mosquito. Then, Kidang Rebut Muring can be define as the deer who disturbed by the bug. This movement can be seen in Condong Balinese Dance. The movement is involving the hands which crossed in front of the dancer face. Then, the feet also crossed and walk crosses to the right or left. When, the dancer walk crosses to the left or right side, it followed by the hand that opened every footrest. In additional, if the dance moves to the left side, so the left foot crossed in front of the right foot, and vice versa.

\section{Mebeh Ngajeg}

Mebeh Ngajeg belongs to compounding of word formation process which there are two words that can be combined become one new word. Mehbeh Ngajeg in Balinese Dance means Mebeh Ngajeg is the position of the legs. One of the leg is on tiptoe then it's vibrated. The right or left legs is facing forward with the heel on tiptoe and the knee is banded.

\section{Manis Cerengu}

Manis Cerengu also belongs to compounding, because there are two words that combined i.e. Manis and Cerengu. Manis means sweet in English. Cerengu means wrinkling the eyebrows and opened the eyes slighlt. Actually, in Balinese Dance Manis Cerengu means the expression of showing the sweetest smile which followed by the eyes that opened in order to make the expression looks clearly.

\section{b.Reduplication}

Reduplication is the formation word through doubling the morpheme (Nurhayati, 2016). Then, according to Zapta (2007) it is a repetition of the word that already existed becomes a new word and it called total reduplication, because it repeats all of the word that exists. based on the explanation before, the researcher can categorized the jargons that belong to reduplication from the data found namely Ulap - ulap and Aras - arasan. The, Balinese define Ulap - ulap as movement in which it looks like waving to call a person or seen something far. Yet, in Balinese Dance it belongs to hands movement which the hands move above to the dancer's head with the palms facing up. While, arasarasan In Balinese dance means expression of love. The dancer will hold their friend's 
hands and take a face-to-face position. Then, the dancers move their head to the right side and the left side in turns.

\section{c. Affixation}

The affixation according to the position in the word is classified into three classes and those are prefix, in fix, and suffix. Prefix is the bound morpheme that added the beginning of the word, the infix one is the bound morpheme that added in the middle of the word, and the suffix is the bound morpheme that added at the back of the word (Zapta, 2007). There are 10 jargons that discovered belong to affixation.

1. Nyeregseg

Nyeregseg is come from a process of derivational affixation in which there are prefix added to produce new word from the lexical of word itself. The process of this word formation is come from the word Seregseg. According to Seregeg (2003), if Balinese changes noun to the verb, but there is consonant letter at the beginning of the lexical word, so it adds the prefix. Then, he mentioned that the consonant letter specially " $\mathrm{C}, \mathrm{J}, \mathrm{S}$ " it adds prefix "Ny" and the consonant lerter at the beginning must be deleted automatically. Nyeregseg come from the process of $\mathrm{Ny}+$ Seregseg, then the later "S" of "Seregseg" must be deleted becomes $\mathrm{Ny}+$ eregseg $=$ Nyeregseg which means the feet on tiptoe and shifted to the side through moving the feet quickly in Balinese Dance.

2.Nyeledet

Nyeledet processed thourgh word formation of derivational affixation which got a prefix "Ny" of the lexical "Seledet". It becomes Nyeledet from the process of prefix "Ny" + "Selede"t $=$ Nyeledet. As we know that every consonant letter that exist at the beginning of the lexical word, so the consonant letter must be deleted automatically. Here, Nyeledet at Balinese Dance means movement of two eyes in which they have to open the eyes as big as dancer can. Then, the eyes will be moved by the dancer to the right or left followed by the chin to the right or left automatically.

3.Nyegut

Nyegut comes from the word cegut in Balinese. It becomes Nyegut caused there is prefix that changed the noun to the verb. Theoretically, in Balinese word formation Cegut becomes Nyegut caused prefix "Ny" and the letter at the beginning of the word Cegut have to delete automatically in order to make a new word of verb. The formation was $\mathrm{Ny}+\mathrm{Cegut}=$ Nyegut. Literally, Nyegut means biting, but in term of Balinese dance it means the movement of neck and chin whereas the chin pulled close to the neck, at the same time the eyes look down and the eyebrows wrinkled automatically.

4.Nyeleog

Nyeleog belongs to affixes of word formation. There is prefix "Ny" of the word Seleog. There is Ny + Seleog = Nyeleog, because if there was prefix "Ny" of the latter $\mathrm{C}, \mathrm{S}$, or $\mathrm{J}$ at the beginning of the word it should be deleted. Then, the term Nyeleog in Balinese Dance means the movement which the body is bended to the right side and to the left side in turn and it followed by the hand that stretch outside along.

5.Nyalud

Nyalud belongs to affixation. Actually, Nyalud comes from the word Salud. Here, the word Salud get a prefix "Ny" and the letter "S" of Salud must be deleted in which it appropriates with the word formation of Balinese. Therefore, $\mathrm{Ny}+\mathrm{Salud}=\mathrm{Nyalud}$ that has meaning the movement of wrist that folded. Folded means the wrist move followed three steps in which this movement shown folded. The first step is the palms faced each 
other and the fingers facing down. The second is the palms facing down and the fingers meet each other. The third is the palms facing up and all of the fingers meet each other. So, from those steps this movement seen as hands folded.

6.Ngepik

Ngepik belongs to affixation of word formation. There is prefix " $\mathrm{Ng}$ " at the word "Kepik", so if "Ng"+ "Kepik" = "Ngepik", because in Balinese word formation when there is letter " $\mathrm{K}$ " at the beginning of word and there is added prefix, so the letter " $\mathrm{K}$ " should be deleted. Yet, actually Ngepik in Balinese Dance means the movement of the wrist which moves up and down in turn. The position of the hand is in front of the chest and the palms are meets each other. This movement followed by the legs that crossed and walk to the right or to the left side followed by the movement of the head which appropriate with the footrest.

7.Ngumbang

Ngumbang shaped from the word "Kumbang", there is added prefix "Ng" in front of word "Kumbang", so it changes become verb. The prefix "Ng" + "Kumbang" = "Ngumbang", it is because the word has the letter " $\mathrm{K}$ " in frnt of the word and if it added prefix, so the " $K$ " itself must be deleted, then change become Ngumbang. If, the word Kumbang described it means beetle in English. Yet, in Balinese Dance it is an imagery of the walking movement that move like a beetle which is flying to the right and to the left side, but in Balinese Dance the dancer walks to the right and to the left side.

8.Ngelung

Ngelung is the term in Balinese Dance that belongs to affixation of word formation. It belongs to affixation, because there is prefix "Nge" of the word Lung which means fracture. Yet, in Balinese Dance the term Ngelung means the movement that involved hands and body. The right or left hands position stretches to the right or to the left that followed by the body to the right or to the left that correspond with the stretched hand and the stretched one bended. Then the other hand is in front of the breast shaped right angle. Furthermore, one of the feet is tiptoe following the direction of the stretched hand

9.Ngegol

Ngegol is come from the word Egol. Here, the word Egol get a prefix "Nge" without deleting the first word of the word Egol, because the first letter is " $E$ " not " $C, J$, or S". Therefore, the term Ngegol can be formed from $\mathrm{Ng}+$ Egol = Ngegol. Then, in Balinese Dance it means the walking movement which usually used to walk in place or to move to one place to another. As usual, the walking movement involved the feet, head, and bottom that move along unidirectional followed the footrest itself.

10. Nyogok

Nyogok is the term in Balinese Dance that comes from the word Sogok. The word Sogok get prefix "Ny" that added at the first of the word Sogok with deleting the letter "S" $(\mathrm{Ny}+\mathrm{Sogok}=\mathrm{Nyogok})$ as the rule of Balinese's word formation. Therefore, the term Nyogok belongs to the affixation especially derivational affixes in which there is reformation of noun becomes verb without reducing the meaning of the word Sogok. In Balinese Dance Nyogok means the movement of the body that pushed to the right or to the left used to process the Agem Kanan (Right Agem) or Agem Kiri (Left Agem). When, the dancer wants to process Agem Kanan, so the body push to the right side with the bottom stay on the left side and the head fall down to the left. Then, the right hand is equal to the right eye, while the left hand is equal to the left breast in which both of the palms are facing to the right and vice versa to the left. 


\section{d. Word Class}

Word refers to a basic of language that has meaning. There are two kinds of word, such as content and function word. According to Aarts \& Haegeman (2008) that word classes are consists of noun, verb, adjective, and adverb, whereas the function word consists of conjunction, articles, preposition, and pronoun. Based on the categorized of the jargons, the researcher will be discussed the jargons which is belong to the word class. There are found 12 jarons that consists of 10 nouns and 2 verbs.

1. Nelik

Nelik is belongs to word class of verb, because it is an action that found in Balinese Dance. According to context of conversation that made through interviewer of Balinese Dancer, Nelik means the action of Balinese Dancers when they in situation of mad. The Dancers opened their eyes bigger than usual and their eyebrows were raised.

2. Nuding

Nuding also belongs to verb of word class that provided. Nuding is an action of Balinese Dance that acted like pointing someone. Appropriate to the name of Nuding, in Balinese Nuding means pointing someone. According to the interviewer of Instructor of Balinese Dance and Student of Balinese Dancer that Nuding is the characteristic of this position which is the right hand is move forward in front of the chest and followed by the forefinger and middle finger pointing to the object.

3. Ngutek

Ngutek is a movement in Balinese Dance that belongs to noun of word class. It is the name of the movement itself and the characteristic of this movement is the body fall down to the right or to the left side which followed by the hands that one hand equal to the eyes and another hand equal to the breast, then the palms is facing forward. Here, the important parts of body that move are head, wrist, and the legs. They move to the right or to the left side following the footrest.

4. Ngelikas

Ngelikas is a noun of word class, because it belongs to the name of the movement that involved the feet that crossed. In Balinese Dance Ngelikas is the movement of legs that crossed. It can be the left leg that put in front of the right leg which is the legs at the back is tiptoe, and vice versa. Then, the hand position is equal to the breast. Actually, this movement is moving from the behind and rotate to forward while the wrist is slue inside. Then the position of hand is equal to the breast in which the right hand is stretches to the right side and the left side is shaped right angels.

5. Ngumad

Ngumad is a noun of word class. It is the name of a movement of Balinese Dancer that pulled the body after conducting the pushed movement. Ngumad can be defined as the pull of body movement. Usually, this movement conducted after do ngeregeh movement. The position of body will skew forward. Then, the knee will banded and the hand (right or left) automatically stretch in which the fingers of the hand is facing back, and the other hand position is equal to breast.

\section{Ngeregeh}

Ngeregeh also belongs to the noun of word class, because it is the name of the movement which moving like push the body to the right and to the left side in Balinese Dance. Actually, the meant by Ngeregeh is the movement that involved the feet which is on tiptoe and the hands move to the right or left side following the direction of the body which is one of the hand is equal to the eyes and another hands is equal to the 
breast which followed by the palms facing to the right or the left side according to the direction of Ngeregeh itself.

7. Ngelo

Ngelo belongs to the noun, because it is a name of the movement that used in Balinese Dance. The meant by Ngelo is the movement of body that arched to the right to rearward to the left and vice versa. This movement followed by the hands that correspond with the body's direction. Ngelo usually done through sit position which is the dancer occupied her/his feet that already banded to the backs.

8. Ngeseh

Ngeseh belongs to noun of word class, because it is the name of the movement which used in Balinese Dance. Here, the researcher found the meaning of Ngeseh through conducted the conversation with the instructor of Balinese dancer and the student of Balinese Dancer. The meant by Ngeseg is the movement of shoulders which is shaking quickly. Then, the position of Ngeseh is hands equal to the breast and the body skewed forward with the knee banded.

9. Nyelekenting

Nyelekenting is the name of the position itself. Therefore, Nyelekenting belongs to the noun of word class. Appropriate with the context of conversation with the instructor of Balinese Dance and the student of Balinese Dancer, the researcher can cover the meaning of Nyelekenting is the position of feet which is their toes is facing up. Yet, in conducting the Agem one of them conduct it

10. Nyempurit

Nyempurit is a noun of word class. It is because Nyempurit is the name of position of Balinese Dance itself. Then, Nyempurit means the position of the fingers in which the mother finger and the middle finger meet each other.

11. Ngontel

Ngontel also belongs to the noun. It is the name of the movement that exists in Balinese Dance. This moement can be seen in Condong Balinese Dance which has characteristic walking movement same as Ngegol. Yet, this movement followed by the hands especially wrist that take a position the left hand is equal to eyes and the right hand is equal to the breast. Then, the wrist moves to the right side along with both of the hands and head following the footrest.

12. Selier

Selier belongs to noun of word class, because it is the name of movement of the eyes that used in Balinese Dance. Actually, selier means eyes movement in which one of them will be closed (right or left) and it will be followed by head rotating to the right or left which correspond with the eyes that closed.

\section{CONCLUSION}

In conclusion, this study was conducted three months in Sanggar Seni Manik Uttara that located at Jalan Samratulangi, Gang Garuda, Nomor 2A, Penarukan, Singaraja - Bali. This study already answered three research questions that consist of the form of jargons, the meaning of jargons, and the functions of jargons used by female Balinese dancer at Sanggar Seni Manik Uttara. Then, from the data of observation and interview, the result that found by the researcher there are 41 jargons used by female Balinese Dancer at Sanggar Seni Manik Uttara discovered. Those forms of the jargons used by female Balinese Dancer at Sanggar Seni Manik Uttara were classified by the researcher based on the word formation process and word class. There are 17 
compounding, 2 reduplications, 10 affixations, and 12 word classes that consist of 10 nouns and 2 verbs. Those forms of jargons were gotten through the context of Instructor and student of Balinese Dancer conversation. The researcher found the meaning of the jargons through conducted the conversation with the instructor and students of Balinese Dancer at Sanggar Seni Manik Uttara. The Instructor and the student of Balinese Dancer at Sanggar S4eni Manik Uttara explained the meaning of those jargons as well. Furthermore, those jargons were used to make the communication easier, avoided the miscommunication, the instructor can manage the time effectively when conducting the practice and also it would make the people outside aware about the meaning of the jargons. Moreover, it would create the solidarity of each team when they talked about Balinese Dance. Based on the finding, the researcher also provides three suggestions that can be explained as follows: (1) The researcher has suggested to the Balinese Dancer's Instructor to use the result of this study in practicing Balinese Dance to the new generation of youth of Balinese Dancer. Balinese Dancer's Student; (2) The study was expected to be used to a learning resource to understand the form, meaning, and the function which will be used to create a good communication among the people around the Balinese art and shared the culture of Balinese dance to the others people, even it doesn't Balinese; (3) This study expected to be reference the other researcher when conducted the similar study, such as language variety, sociolinguistics, communication case, and etc. The researcher advised that other researcher has to explore deeply about the phenomenon related to sociolinguistics, language variety, jargons which exist in a group, job, and profession.

\section{REFERENCES}

Agarwal, S., \& Garg, A. (2012). The Importance of Communication within Organizations: A Research on Two Hotels in Uttarakhand. IOSR Journal of Business and Management (IOSRJBM), 40-49.

Andiani, G. (2017). An Analysis of Jargons Used by Nursing Students at Grade XI in SMK Negeri 1 Kubutambahan. Singaraja: Universitas Pendidikan Ganesha.

Armstrong, E., \& Ferguson. (2010). Language, meaning, context, and functional communication. Research Online, 480-496.

Aarts, B., \& Haegeman, L. (2008). Word Clases and Phrase. London: University College London.

Bekhet, A., \& Zauszniewski, J. (2012). Methodological Triangulation: An Approach toUnderstanding Data. e-Publications@ Marquette, 40-43.

Davies, S. (2015, August 12). Beauty, Youth, and the Balinese Legong Dance. Research Gate, pp. 1-35.

Elo, S., Kääriäinen, M., Kanste, O., Pölkki, T., Utriainen, K., \& Kyngäs, H. (2014). Qualitative Content Analysis: A Focus on Trustworthiness. Sage Open, 1-10.

Fardah. (2015, December 8). Antaranews.com. Retrieved April 4, 2019, from Antara News: https://en.antaranews.com/news/101911/unescos- recognition-ofbalinese-dances-to-help-promote-indonesian-tourism

Heryadi, Y., Fanany, M., \& Arymurthy, A. (2012). Grammar of Dance Gesture from Bali Traditional Dance. IJCSI International Journal of Computer Science Issues, 144-149. 
Heryadi, Y., Fanany, M., \& Arymurthy, A. (2012). Grammar of Dance Gesture from Bali Traditional Dance. International Journal of Computer Science, 149.

Januhari, N., Sarja, N., \& Rudita, M. (2018). Information Technology Based ModelL for Balinese Classical Dance Preservation. International Journal of Engineering Technologies and Management Research, 71-85.

Liaw, J., Dani, N., \& Johari, A. (2013). Language Usage of Jargon and Slang in Strategic Studies. Australian Journal of Basic and Applied Sciences, 661- 666.

Mackrell, J. (2019, January 16). Encyclopaedia Britannica. Retrieved April 4, 2019, from Encyclopaedia Britannica: https://www.britannica.com/art/dance

Novianti, D. (2017). Word Formation Analysis Of English Slang Language On Deadpool Movie. Jakarta: State Islamic University Syarif Hidayatullah.

Nurhayati, D. (2016). Word Formation Processes and a Technique in Understanding Waria Slang Tulungagung. EFL JOURNAL, 59-87.

Seregeg, I. (2003). Wyakarana Kawi. Buleleng: Indra Jaya.

Solgi, F., \& Tafazoli, D. (2018). The necessity of teaching culture in English as a foreign language course: Iranian perspective. Journal Of Language And Linguistic Studies, 01-11.

Wright, N. (2010, January 10). Plainlanguage.gov. Retrieved January 20, 2019, from An official website of the United States government: https://www.plainlanguage.gov/resources/articles/keep-it-jargon-free/

Yasmin, S., \& Rahman, K. (2012). Triangulation' Research Method as the Tool of Social Science Research. BUP Journal, 154-163.

Yazdanifard, R., \& Patoko, N. (2014). The Impact of Using Many Jargon Words, while Communicating with the Organization Employee. American Journal of Industrial and Business Management, 567-572.

Zalta, E. (2018). The Philoshopy of Dance. The Stanford Encyclopedia of Philosophy, $1-33$.

Zapta, P. (2007). Types of Words and Word-Formation Processes in English. Inglés IV (B-2007), 1-23. 